\title{
JUKMAS
}

\section{Faktor Faktor Risiko Yang Berhubungan Dengan COVID 19 : Literature Review}

\author{
Wuri Ratna Hidayani ${ }^{1}$ \\ Program Studi Kesehatan Masyarakat, STIKes Respati \\ wuri.ratnahidayani@gmail.com
}

\begin{abstract}
Abstrak
Prevalensi kasus Covid-19 di dunia pertengahan September 2020 mencapai 29.155.581 dan kematian tercatat 926.544 jiwa dengan tersebar ke 216 negara sehingga Case Fatality Rate sebesar 3,17\% (WHO, 2020). Tujuan penelitian ini untuk mengetahui faktor-faktor risiko yang berhubungan dengan Covid 19. Metode penelitian ini adalah studi literature dengan jurnal penelitian berbahasa inggris tahun 2020 dengan rancangan penelitian analitik dengan data yang mendukung faktor-faktor risiko Covid 19. Dalam penelurusan jurnal dengan bantuan internet dengan kata kunci terkait faktor risiko, karakteristik,komorbid dan Covid 19. Kesimpulan dari penelitian ini umur, jenis kelamin, pasien yang terinfeksi di rumah sakit, penyakit komorbid ,tanda dan gejala Covid 19 berhubungan dengan Covid 19. Riwayat merokok tidak berhubungan dengan COVID 19. Rekomendasi diharapkan masyarakat berperilaku sehat memperkecil perilaku berisiko Covid 19 dengan mematuhi protokol kesehatan.
\end{abstract}

Kata kunci: faktor risiko, karakteristik, komorbid, Covid 19

\begin{abstract}
The prevalence of Covid-19 cases in the world in mid-September 2020 reached $29,155,581$ and 926,544 deaths were recorded in 216 countries, so that the Case Fatality Rate was $3.17 \%$ (WHO, 2020) [1]. The purpose of this study is to determine the risk factors associated with Covid 19. This research method is a literature study with an English-language research journal in 2020 with an analytical research design with data that supports the risk factors for Covid 19. In researching journals with the help of the internet with keywords related to risk factors, characteristics, comorbids and Covid 19. The conclusion of this study is age, sex, infected patients in hospital, comorbid diseases, signs and symptoms of Covid 19 are related to Covid 19. Smoking history is not related to COVID 19 Recommendations are expected that people behave in a healthy manner to reduce risky behavior for Covid 19 by complying with health protocols
\end{abstract}

Keywords : risk factors, characteristics, comorbids, Covid 19

http://ejournal.urindo.ac.id/index.php/jukmas

Article History :

Submitted 01 Oktober 2020, Accepted 30 Oktober 2020, Published 31Oktober 2020 


\section{PENDAHULUAN}

Dunia dewasa ini menghadapi pandemi Covid 19 yang menyebar pada 216 negara dengan kasus sudah mencapai 29 juta . Berbagai upaya kebijakan dunia dalam mencegah penyebaran Covid 19 yang kasusnya terus meningkat tajam yaitu dengan lockdown, menjaga jarak, mencuci tangan dengan sabun dan air mengalir serta penggunaan masker. Pada Desember 2019 Italia sebesar 10,19\%, Indonesia sebesar $8,73 \%$, China sebesar 4,04\% dan Amerika Serikat 1,44\% (Hidayani, 2020) [2]. Epidemiologi Covid 19 meliputi agent, host and environment. Agent Covid 19 adalah 2019 novel Coronavirus (2019-nCov), Severe acute respiratory syndrome coronavirus-2 (SARS-CoV-2), penyakitnya disebut Corona virus diseases 2019 (Covid 19) (WHO, 2020) [1]. Host penyakit ini adalah manusia terutama kelompok yang rentan atau berisiko serta imunitasnya rendah. Karakteristik pejamu dapat dipengaruhi oleh berbagai faktor status gizi, imunitas. Environment penyakit ini adalah lingkungan yaitu lingkungan fisik seperti sanitasi lingkungan yang buruk, lingkungan biologi contohnya kepadatan penduduk, virulensi virus,lingkungan sosial budaya seperti perilaku, lingkungan ekonomi, politik. Faktor risiko terbagi menjadi faktor risiko yang tidak dapat diubah seperti umur, jenis kelamin, ras, suku, genetik termasuk adanya kasus pneumonia yang serius yang sebelumnya belum teridentifikasi etiologinya. Pada mulanya kasus ini sebanyak 44 kasus bermula di Wuhan, Cina yang menyebar begitu sangat cepat sampai saat ini berjumlah puluhan juta jiwa kasus (Perhimpunan Dokter Paru Indonesia, 2020) [3]. Berdasarkan data dunia per Maret 2020 case fatality rate tertinggi adalah

riwayat penyakit karena genetik. Sedangkan changeable risk factors yaitu perilaku tidak sehat sehingga menyebabkan penyakit komorbid seperti hipertensi, diabetes, penyakit kardiovaskuler, penyakit paru. Dalam upaya pencegahan dapat dilakukan memodifikasi faktor pejamu dan faktor lingkungan dalam memutus rantai penularan Covid 19. Upaya pencegahan Covid 19 dengan five level of prevention seperti health promotion dengan cara upaya penyuluhan, bina suasana, advokasi; specific protection dengan cara menggunakan masker, handsanitaizer dan mencuci tangan dengan sabun dan air mengalir, melindungi diri untuk tetap berada di rumah, early diagnosis dengan screening contohnya rapid test dan $\mathrm{PCR}$, disability limitation memonitoring pengobatan Covid 19; rehabilitation dengan pengobatan intensif di rumah sakit dengan pengobatan antiviral dan obat lainnya. 
METODE

Metode penelitian ini adalah studi literature dengan jurnal penelitian berbahasa inggris tahun 2020 dengan rancangan penelitian analitik dengan data yang mendukung faktor-faktor risiko covid 19. dalam penelurusan jurnal dengan bantuan internet dengan kata kunci terkait faktor risiko, karakteristik,komorbid dan covid 19. penelurusan jurnal pada literature review ini hasil penelurusan google scholar sebanyak 151 jurnal, jurnal yang tidak relevan dengan tujuan 100 jurnal yang relevan dengan tujuan sebanyak 51 jurnal. jurnal yang tidak eligible dengan kriteria inklusi adalah 46 jurnal. jurnal yang eligible dengan kriteria inklusi sebanyak 5 jurnal.

\section{HASIL DAN PEMBAHASAN}

\section{A. HASIL}

Hasil studi literature review sebagai berikut :

Tabel 1 Hasil Studi Literature Review

\begin{tabular}{cccc}
\hline $\begin{array}{c}\text { Penulis, Judul dan } \\
\text { Tahun }\end{array}$ & Daerah & Tujuan & Metode
\end{tabular}

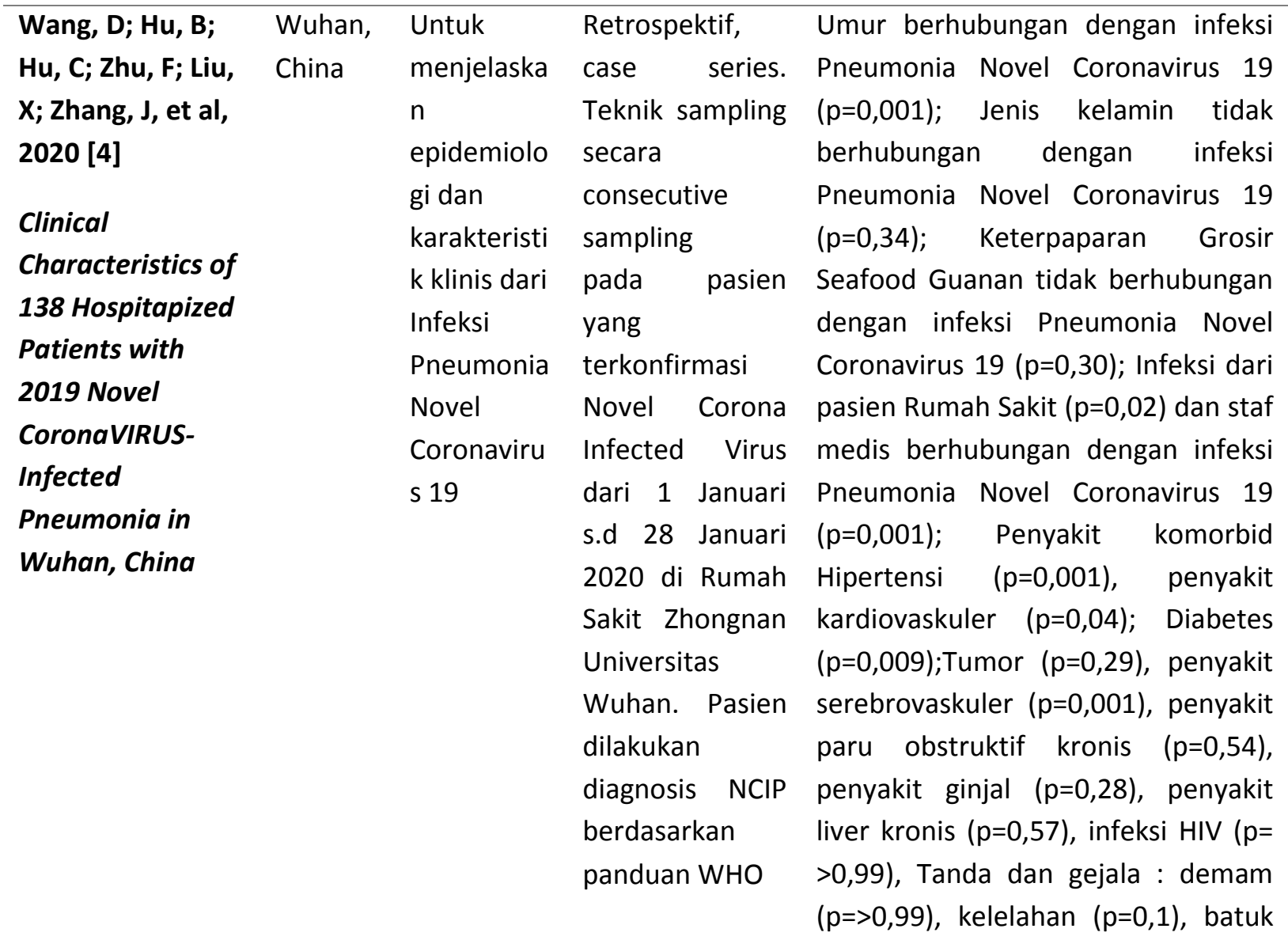




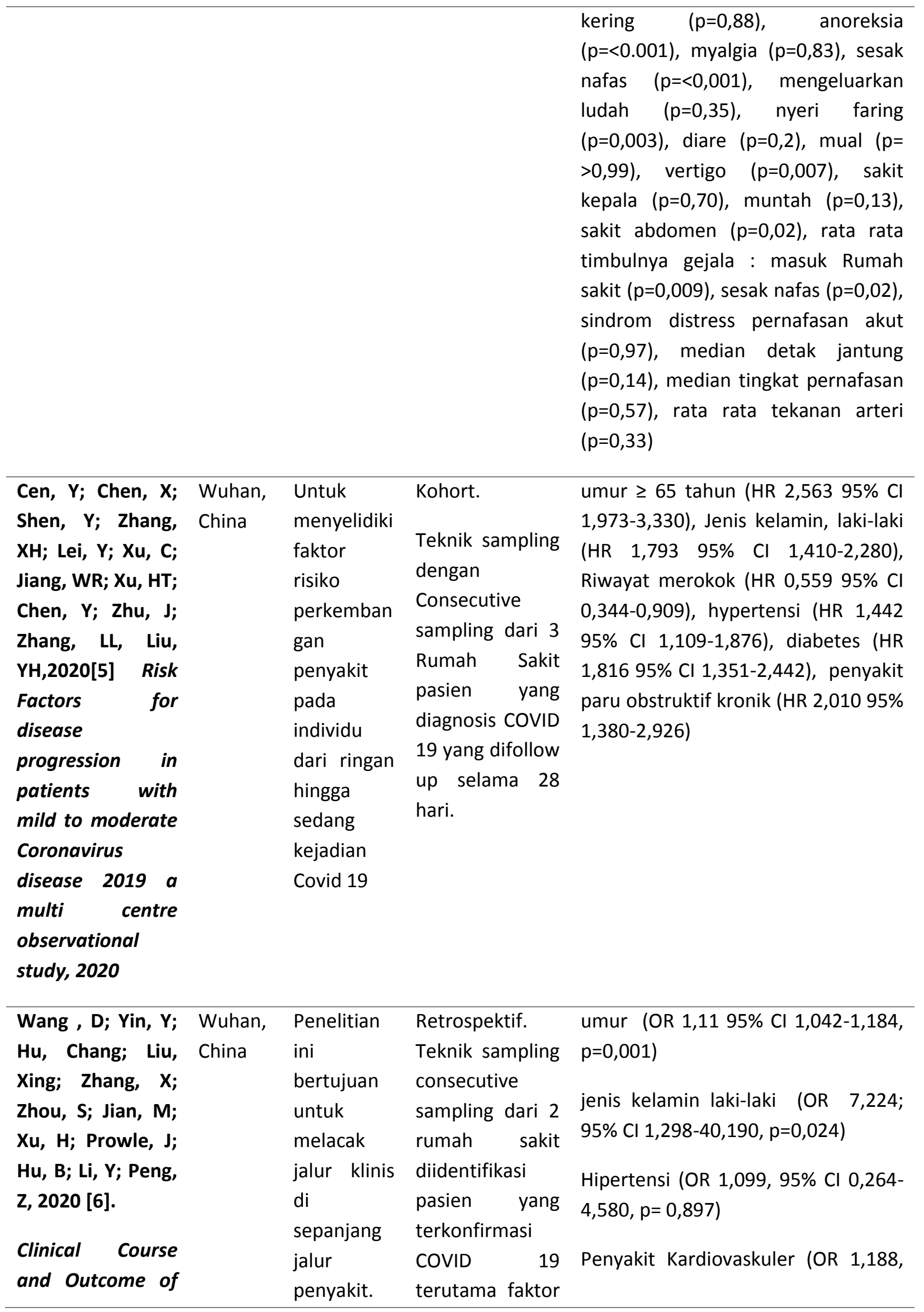




\begin{tabular}{|c|c|c|c|}
\hline $\begin{array}{l}107 \text { patient } \\
\text { infected with the } \\
\text { Novel } \\
\text { Coronavirus } \\
\text { SARS-CoV-2, } \\
\text { discharged from } \\
\text { two hospital in } \\
\text { Wuhan, China }\end{array}$ & $\begin{array}{l}\text { Selain itu } \\
\text { melakukan } \\
\text { analisis } \\
\text { faktor } \\
\text { risiko } \\
\text { untuk } \\
\text { mengungk } \\
\text { apkan } \\
\text { gambaran } \\
\text { klinis } \\
\text { penting } \\
\text { yang } \\
\text { terkait } \\
\text { dengan } \\
\text { outcome } \\
\text { yang tidak } \\
\text { baik pada } \\
\text { pasien } \\
\text { Covid } 19\end{array}$ & $\begin{array}{lr}\text { risiko } & \text { serta } \\
\text { dibandingkan } \\
\text { yang } & \text { survivor } \\
\text { dan } & \text { non } \\
\text { survivor } & \end{array}$ & $\begin{array}{l}95 \% \mathrm{Cl} 0,182-7,765, p=0,857) \\
\text { Konsentrasi kreatinin (OR 1,012, 95\% } \\
\mathrm{Cl} 0,987-1,037, p=0,342 \text { ) }\end{array}$ \\
\hline
\end{tabular}

\begin{tabular}{|c|c|c|c|c|}
\hline 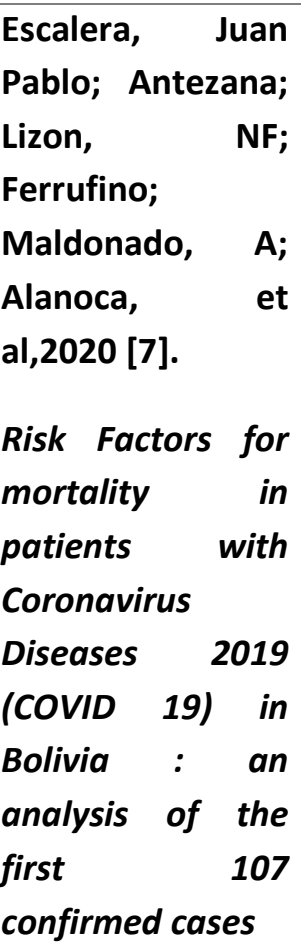 & Bolivia & $\begin{array}{l}\text { Untuk } \\
\text { menganalis } \\
\text { is } \\
\text { hubungan } \\
\text { faktor } \\
\text { risiko } \\
\text { kematian } \\
\text { yang } \\
\text { terkonfirm } \\
\text { asi Covid } \\
19 \quad \text { dan } \\
\text { membandi } \\
\text { ngkan } \\
\text { pasien } \\
\text { yang } \\
\text { survive }\end{array}$ & $\begin{array}{l}\text { Crossectional } \\
\text { Retrospektif. } \\
\text { Pengumpulan } \\
\text { data } \\
\text { epidemiologi } \\
\text { dari Rumah } \\
\text { Sakit di Bolivia } \\
\text { yang } \\
\text { terkonfirmasi } \\
\text { COVID 19selama } \\
28 \text { hari dan data } \\
\text { dari Kementrian } \\
\text { Kesehatan } \\
\text { berdasarkan } \\
\text { diagnosis } \\
\text { laboratorium } \\
\text { dan test PCR }\end{array}$ & $\begin{array}{l}\text { Umur ( dewasa) ( OR : 9,393 95\% Cl: } \\
\text { 1,847-104,081, } p<0,05 \text { ) } \\
\text { Hipertensi (OR : 3,284 95\% Cl :1,276- } \\
6,291, p<0,05) \\
\text { Masuk Rumah Sakit, gagal jantung } \\
\text { kronis, Diabetes, penyakit komorbid } \\
\text { lain, obesitas, jenis kelamin tidak } \\
\text { berhubungan dengan Covid } 19 \\
\text { ( } p>0,05)\end{array}$ \\
\hline $\begin{array}{l}\text { Cumming, } \\
\text { Matthew; } \\
\text { Baldwin, }\end{array}$ & $\begin{array}{l}\text { New } \\
\text { York } \\
\text { City }\end{array}$ & $\begin{array}{l}\text { Mengidenti } \\
\text { fikasi } \\
\text { paasien }\end{array}$ & $\begin{array}{l}\text { Kohort } \\
\text { Prospektive. } \\
\text { Pengumpulan }\end{array}$ & $\begin{array}{l}\text { Umur HR 1,31 95\% (1,09-1,57), Jenis } \\
\text { kelamin laki-laki HR } 1,31 \mathrm{Cl} 95 \% \text { ( } \\
0,71-1,81) \text {; lamanya gejala sebelum }\end{array}$ \\
\hline
\end{tabular}




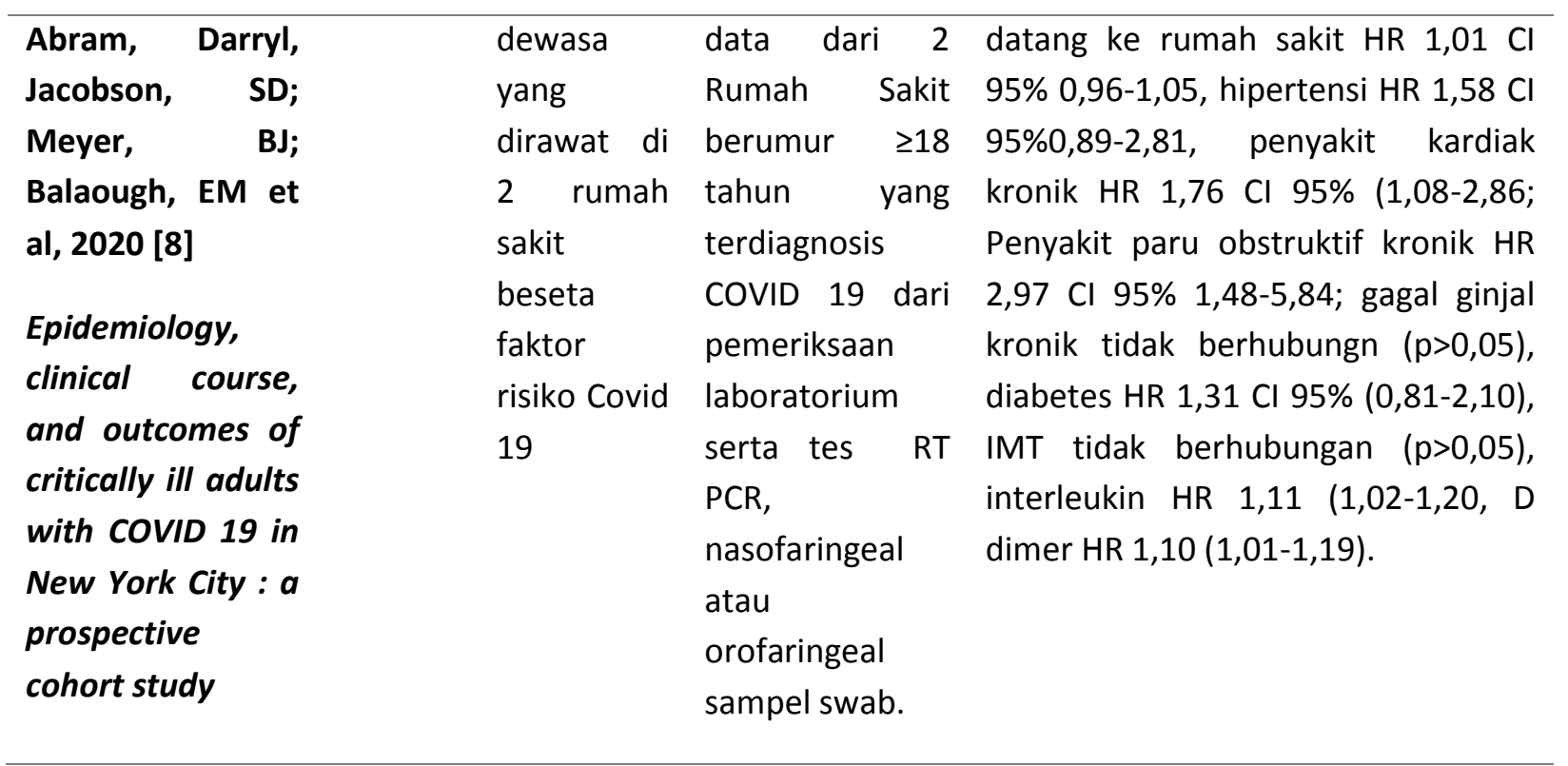

Berdasarkan hasil literature review jurnal yang diperoleh, faktor-faktor risiko yang berhubungan dengan COVID 19 terdiri dari

1. Karakteristik Individu

Berdasarkan kajian literature karakteristik individu terutama pasien atau penderita yang berhubungan dengan COVID 19 antara lain:

a. Umur

Kajian literature dari 5 jurnal penelitian yang menunjukkan hubungan antara umur dengan COVID 19 semua jurnal menyatakan ada hubungan yang signifikan. Data pertama dari jurnal pertama menunjukkan $p<0,05$ antara umur dengan COVID 19. Data kedua menunjukkan yang paling dominan adalah umur $\geq 65$ tahun dengan HR 2,563 artinya orang atau pasien yang berumur $\geq 65$ tahun berisiko
2,6 kali lebih besar terserang COVID 19 dibandingkan umur kurang dari 65 tahun. Data ketiga dari jurnal ketiga menunjukkan $\mathrm{OR}=1,11$ bahwa orang yang berumur $>75$ tahun berisiko $1,11 \mathrm{kali}$ terkena COVID 19 dibandingkan usia dibawah 75 tahun. Data ke empat dari jurnal keempat menunjukkan bahwa orang yang berumur $>60$ tahun berisiko 9,393 terkena COVID 19 dibandingkan yang umur dibawah 60 tahun. Data kelima dari jurnal kelima menunjukkan proporsi pasien terbanyak pada usia 60-69 tahun dengan jumlah 69 pasien (27\%), hasil bivariate dan multivariate menunjukkan umur di 
atas 62 tahun berisiko 1,31 kali

lebih besar dibandingkan umur dibawah 62 tahun. Menurut Escalera (2020) menyatakan bahwa faktor umur berisiko COVID 19 dikarenakan orang dengan usia lanjut ditambah dengan menderita penyakit-penyakit komorbid COVID 19 seperti hipertensi[7]. Chen (2020) menyatakan bahwa penderita COVID 19 disertai penyakit penyerta akan memperparah dan berakibat fatal pada kematian [5]. Salah satu penyakit penyerta adalah stroke infark akan memperparah dan berisiko kematian pada penderita COVID 19. Faktor umur erat kaitannya dengan COVID 19 karena orang yang lanjut usia adanya proses degeneratif anatomi dan fisiologi tubuh sehingga rentan terhadap penyakit, imunitas yang menurun, ditambah seseorang yang mengidap penyakit penyerta akan menyebabkan kondisi tubuhnya lemah sehingga mudah terinfeksi COVID 19. Selain itu faktor usia yang lanjut menyebabkan kelalaian dalam menjaga protokol COVID 19 sehingga meningkatkan risiko COVID 19.

b. Jenis Kelamin
Kajian literature dari 5 jurnal penelitian menunjukkan 3 jurnal berhubungan dengan COVID 19 dan 2 jurnal tidak berhubungan dengan COVID 19. Data pertama dari jurnal pertama dan data keempat dari jurnal empat nilai $p>0,05$ artinya tidak ada hubungan antara jenis kelamin dengan COVID 19. Berbeda dengan data dua dari jurnal dua menunjukkan nilai HR 1,793 (lakilaki) artinya laki-laki berisiko 1,793 kali lebih besar terserang COVID 19 dibandingkan perempuan. Data tiga dari jurnal tiga menunjukkan nilai OR 7,224 artinya laki-laki berisiko 7,224 kali lebih besar terkena COVID 19 dibandingkan perempuan. Sejalan juga dengan data lima dari jurnal lima bahwa nilai HR 1,31 menunjukkan bahwa laki-laki berisiko terserang COVID 19 1,31 kali lebih besar dibanding perempuan. Menurut Chen (2020) menyatakan bahwa laki-laki lebih berisiko COVID 19 dikarenakan faktor kromosom dan faktor hormon. Pada perempuan lebih terproteksi dari COVID 19 dibandingkan laki-laki karena memiliki kromosom $x$ dan hormon seks seperti progesteron yang memainkan peranan penting dalam 
imunitas bawaan dan adaptif [5]. Laki-laki biasanya karena tuntutan pekerjaan lebih sering keluar rumah dibandingkan perempuan sehingga rentan penyakit ini. Selain itu perempuan biasanya lebih memiliki tingkat pengetahuan lebih tinggi dibandingkan laki-laki terutama epidemiologi dan faktor risiko COVID 19.

2. Infeksi Nosokomial dari penderita dan staf Rumah Sakit

Menurut kajian literature pada 5 jurnal yang menyatakan adanya hubungan antara infeksi nosocomial baik dari penderita COVID 19 maupun staff Rumah Sakit menunjukkan nilai $p<0,05 \quad(0,001)$ yang berarti hubungan yang signifikan sedangkan 4 jurnal lainnya tidak terdapat variabel ini. Menurut Wang (2020) menyatakan bahwa infeksi nosokomial sangat berbahaya bagi penderita atau pasien lain yang dirawat dan juga orang sehat [4]. Di Rumah Sakit Zhongnan terlaporkan pasien yang awalnya hanya gejala sakit perut kemudian di rawat di RS yang sebangsal dengan pasien COVID 19 akhirnya tertular pasien COVID 19. Selain itu juga lebih dari 10 pekerja di RS tersebut terinfeksi penyakit ini. WHO (2020) memberikan tata laksana pada pasien suspek COVID 19 baik yang ringan maupun penderita COVID 19 dengan tingkatan penyakit yang berat di RS diantaranya harus menerapkan protokol kesehatan yaitu pasien menggunakan masker, pasien yang COVID 19 dipisahkan dari pasien lain, serta pengaturan jarak $1 \mathrm{~m}$, serta petugas RS diwajibkan menggunakan APD lengkap. Keluarga pasien sebaiknya disarankan tidak diperkenankan menjenguk ke rumah sakit demi memutus infeksi nosokomial dan memutus rantai penularan COVID 19[9]. .

\section{Penyakit Komorbid Hipertensi} Tinjauan literature dari 5 jurnal menunjukan bahwa dari kelima jurnal tersebut menunjukkan ada hubungan yang signifikan dengan COVID 19. Data pertama dari jurnal pertama menunjukkan hasil uji statistic yaitu nilai $p=0,001$. Data kedua, ketiga, keempat dan kelima secara berturut turut menunjukkan HR 1,442, OR 1,099, 3,284, 1,58 artinya pasien dengan riwayat penyakit hipertensi berisiko 1,442 ; 
1,099; 3,284; 1,58 kali lebih besar memperburuk kondisi penderita COVID 19 dibandingkan pasien yang tidak menderita hipertensi. Peningkatan kematian Covid 19 adalah adanya komorbid dari hipertensi sebanyak 58,9\% di Afrika dan Amerika (Ferdinans, 2020) [10]. Menurut Zhang, et al (2020) menyatakan bahwa dari 140 pasien dengan covid 19 dengan 37,9 \% pasien covid -19 dengan penyakit hipertensi. Selain itu dilaporkan pasien hipertensi sebanyak 30\% diduga dengan berbagai riwayat penyakit infeksi.. Menurut Li (2020) menyatakan sebanyak $17,1 \%$ pasien dengan dengan riwayat penyakit infeksi salah satunya adalah hipertensi, sehingga hipertensi merupakan komorbid penyakit infeksi salah satunya covid 19 diantara 1.527 pasien yang tersebar dirawat pada ICU dan non ICU[11]. Beberapa penelitian menunjukkan penyakit komorbid hipertensi dapat memperparah prognosis COVID 19 disebabkan karena konsumsi obat ACE inhibitor dan ARB sebagai intervensi obat hipertensi ternyata dapat memperparah COVID 19 [12]. Hal ini akan memperburuk kondisi pasien COVID 19 dan meningkatkan risiko morbiditas dan mortalitas COVID 19. Study retrospektif di Cina menunjukkan pasien COVID 19 dengan hipertensi tanpa ACE inhibitor dan ARB terbukti adanya penurunan mortalitas (HR 0,42 95\% $0,19-0,92, p=0,03) \quad[10] . \quad A C E$ inhibitor akan memudahkan virus masuk ke dalam sel dan replikasi yang diakibatkannya [13]. ARB akan menumpulkan AT2 sehingga akan menyebabkan dampak pemicu peradangan dan reaktivitas imun akut di paru paru[14]. Treatment ini yang akan memperparah kondisi COVID 19. Setelah adanya bukti bahwa treatment hipertensi akan meningkatkan risiko COVID 19 sebaiknya alternative pengobatan herbal bisa digunakan dalam menangani hipertensi sehingga tidak memperburuk prognosis COVID 19 dan memperkecil risiko COVID 19.

4. Penyakit Komorbid Kardiovasculer Dalam tinjauan literature ini penyakit kardiovaskuler yang berhubungan dengan COVID 19 terdapat pada data satu atau jurnal pertama dengan nilai $p=0,04$ artinya ada kemaknaan yang significant antara penyakit 
kardiovaskuler dengan COVID 19. Pasien COVID 19 dengan komorbid kardiovaskuler akan memperburuk prognosis COVID 19. Berbeda dengan data tiga atau jurnal tiga (OR 1,188, 95\%Cl 0,182-7,765 , $p=$ 0,857 ) artinya tidak ada hubungan antara penyakit kardiovaskuler dengan COVID 19 tetapi melihat nilai OR 1,188 penyakit kardiovaskuler merupakan faktor risiko artinya penyakit kardiovaskuler akan meningkatkan risiko 1,88 kali lebih besar terserang COVID 19 dibanding yang tidak berpenyakit kardiovaskuler. Orang yang menderita penyakit kardiovaskuler akan diberikan obat yang mengandung ACE 2 dan ARB yang memproteksi paru paru. Sedangkan SARS-CoV2 atau Corona virus menggunakan protein ACE 2 untuk memasuki sel. ACE 2 merupakan protein membrane yang memiliki fungsi fisiologis yaitu proteksi paru paru tetapi merupakan pintu masuk virus dalam tubuh yang akan memyebabkan toksisitas pada kardiovaskuler. Beberapa komplikasi kardiovaskuler setelah terinfeksi COVID 19 antara lain aritmia, miokarditis, sindrom koroner akut, troboemboli vena, syok kardiogenik, gagal jantung [15]. Dalam hal ini meskipun secara medis tidak disarankan penghentian ACE dan ARB tetapi untuk memperkecil risiko COVID 19 sebaiknya adanya alternatif terapi penyakit kardiovaskuler bisa dicoba terapi obat yang tidak memiliki efek samping serta meningkatkan gaya hidup sehat sehingga seseorang terhindar dari COVID 19.

5. Penyakit Komorbid Diabetes Mellitus

Berdasarkan kajian literature menunjukkan pada data pertama atau jurnal satu menunjukkan nilai $p=0,009$ artinya ada hubungan antara penderita diabetes mellitus dengan COVID 19. Pada data dua jurnal dua menunjukka variabel diabetes (HR 1,816 95\% Cl 1,3512,442 ) artinya diabetes mellitus merupakan faktor risiko yaitu orang yang diabetes mellitus berisiko 1,816 kali lebih besar terserang COVID 19 dibandingkan yang tidak menderita diabetes mellitus. Data keempat pada jurnal keempat bahwa diabetes mellitus tidak berhubungan dengan COVID 19 $(p>0,05)$. Data kelima dari jurnal kelima menunjukkan HR $1,31 \mathrm{Cl}$ 
$95 \% \quad(0,81-2,10$ artinya orang dengan diabetes mellitus berisiko 1,31 terserang COVID 19 dibandingkan orang yang tidak diabetes mellitus. Orang yang diabetes mellitus dengan COVID 19 akan meningkatkan meningkatkan sekresi hormone hiperglikemik seperti catecolamin dan glukokorticoid dengan menghasilkan elevasi glukosa dalam darahvariabilitas glukosa abnormal dan komplikasi diabetes [16][17]. Penderita COVID 19 dengan diabetes akan meningkatkan gagal ginjal menyebabkan tidak terkontrolnya diabetes dan hipertensi sebagai komorbid COVID 19 [18]. Dampak tidak terkontrolnya diabetes akan menyebabkan peradangan sitokin yang berakibat kerusakan multi organ [5].

6. Penyakit Komorbid Paru Obstruktif Kronik

Pada kajian literature pada 5 jurnal yang menunjukkan adanya hubungan antara penyakit komorbid paru obstruktif kronik dengan COVID 19 adalah pada data kedua atau jurnal kedua (HR 2,010 $95 \%$ 1,380-2,926) yang artinya bahwa orang dengan penyakit paru obstruktif kronik (PPOK) memiliki risiko 1,380 terserang COVID 19 dibandingkan yang tidak sakit PPOK. Pasien COVID 19 dengan PPOK akan memperburuk prognosis penyakit. Data lima pada jurnal lima menunjukkan PPOK (HR 2,97 Cl 95\% 1,48-5,84) bahwa orang dengan penyakit paru obstruktif kronik (PPOK) memiliki risiko 2,97 terserang COVID 19 dibandingkan yang tidak sakit PPOK. Pada pengobatan PPOK akan membutuhkan ACE dan ARB sebagai perlindungan fisiologis pada paru paru akan tetapi obat tersebut akan memicu masuknya SARCoV2 atau corona virus sehingga peningkatan risiko COVID 19 akan meningkat.

7. Tanda dan Gejala

Pada kajian literature tanda dan gejala yang meningkatkan risiko COVID 19 terdapat pada data satu atau jurnal pertama antara lain : demam $\quad(p=>0,99)$ kelelahan $(p=0,1)$, batuk kering $(p=0,88)$, anoreksia $\quad(p=<0.001)$ myalgia $(p=0,83)$, sesak nafas $(p=<0,001)$, mengeluarkan ludah $(p=0,35)$, nyeri faring $(p=0,003)$, diare $(p=0,2)$, mual $(p=>0,99)$, vertigo $(p=0,007)$, sakit kepala $(p=0,70)$, muntah $(p=0,13)$, 
sakit abdomen $(p=0,02)$. Tanda dan gejala yang signifikan adalah anoreksia, sesak nafas, nyeri faring, vertigo. Pada setiap negara dalam penentuan kriteria tanda dan gejala COVID 19 merujuk pada ketentuan WHO. Di Indonesia pedoman dalam penentuan gejala COVID 19 salah satunya merujuk pada pedoman diagnosis dan penatalaksanaan Pneumonia dan COVID 19 yaitu seseorang dikatakan COVID 19 jika mengalami tiga gejala utama demam, batuk kering (sebagian kecil berdahak) dan sulit bernafas atau sesak. Ada pada sekelompok orang tidak didapati gejala demam pada usia geriatri atau pada orang yang imunokompromis. Gejala COVID 19 juga ada beberapa tambahan gejala seperti nyeri kepala, nyeri otot, lemas, diare dan batuk darah. Selain itu juga adanya tanda dan gejala infeksi saluran nafas berat dengan ketentuan riwayat demam $\geq 38^{\circ} \mathrm{C}$ dan batuk dengan onset 10 hari terakhir serta perlunya rehabilitasi dirawat di Rumah Sakit [3]. Meskipun tanda gejala COVID 19 sudah adanya penetapan dengan minimal 3 gejala tetapi sebaiknya agar tetap waspada dengan senantiasa mematuhi protokol kesehatan dan menjaga PHBS serta melakukan screening dengan PCR atau rapid test. Hal ini karena banyaknya orang tanpa gejala (OTG) yang dinyatakan positif setelah melakukan test.

8. Riwayat Merokok Faktor risiko riwayat merokok dalam kajian literature ini tidak adanya hubungan dengan COVID 19. Tersaji pada data tiga atau jurnal tiga menunjukkan (HR 0,559 95\% Cl 0,344-0,909). Meskipun tidak adanya hubungan hasil HR menunjukkan 0,599 yang artinya orang yang tidak merokok merupakan faktor protektif COVID 19. Menurut Liu (2020) menyatakan bahwa dalam studinya yang berjudul analysis of Factors Associated with Disease Outcome in Hospitalized with 2019 Novel Coronavirus Diseases, menyebutkan 78 pasien penderita Covid 19 selama 2 minggu perawatan ditemukan bahwa 11 pasien memburuk dan 67 pasien kondisinya membaik dengan $27 \%$ dari kelompok yang memburuk memiliki riwayat merokok sementara dari kelompok yang kondisinya membaik hanya 3\% yang 
memiliki riwayat merokok. Merokok menjadi penyebab meningkatnya reseptor ACE2 yang menjadi reseptor virus Corona penyebab Covid 19 [19].

\section{SIMPULAN}

Pada literature review ini disimpulkan antara lain ada hubungan antara umur, jenis kelamin, infeksi nosokomial dari penderita dan rumah sakit, penyakit komorbid (hipertensi, diabetes mellitus, penyakit kardiovaskuler dan PPOK), tanda dan gejala dengan COVID $19 \quad(p<0,05)$. Tidak ada hubungan antara riwayat merokok dengan COVID $19(p>0,05)$. Saran dalam penelitian ini diharapkan masyarakat berperilaku sehat memperkecil perilaku berisiko Covid 19 dengan mematuhi protokol kesehatan seperti mencuci tangan dengan sabun dan air mengalir, menggunakan masker dan menjaga jarak $1 \mathrm{~m}$, menghindari faktor risiko changeable risk factors dengan berperilaku sehat.

\section{DAFTAR PUSTAKA}

[1] WHO.2020. Coronavirus disease (COVID 19) pandemic.https://who.int. diakses tanggal 20 September 2020

[2] Hidayani WR. 2020. Epidemiologi. Deepublish. Yogyakarta
[3] Perhimpunan Dokter Paru Indonesia. 2020.Pneumonia COVID 19 Diagnosis dan Penatalaksanaan di Indonesia.

[4] Wang, D; Hu, B; Hu, C; Zhu, F; Liu, X; Zhang, J, et al. 2020. Clinical Characteristics of 138 Hospitapized Patients with 2019 Novel CoronaVIRUS-Infected Pneumonia in Wuhan, China.JAMA.Original Investigation. 2020;323(11):10611069

[5] Cen, Y; Chen, X; Shen, Y; Zhang, XH; Lei, Y; Xu, C; Jiang, WR; Xu, HT; Chen, Y; Zhu, J; Zhang, LL, Liu, YH. 2020. Risk Factors for disease progression in patients with mild to moderate Coronavirus disease 2019 a multi centre observational. Clinical Microbiology and Infection.www.clinicalmicrobiologya ndinfection.

[6] Wang, D; Yin, Y; Hu, Chang; Liu, Xing; Zhang, X; Zhou, S; Jian, M; Xu, H; Prowle, J; Hu, B; Li, Y; Peng, Z. 2020. Clinical Course and Outcome of 107 patient infected with the Novel Coronavirus , SARS-COV-2, discharged from two hospital in Wuhan, China. BMC.(2020)24:188, p: $1-9$

[7] Escalera, Juan Pablo; Antezana; 
Lizon, NF; Ferrufino; Maldonado, A; Alanoca, et al.2020. Risk Factors for mortality in patients with Coronavirus Diseases 2019 (COVID 19) in Bolivia : an analysis of the first 107 confirmed cases. Le Infozioni in Medicina,n.2,238-242,2020

[8] Cumming, Matthew; Baldwin, MR; Abram, Darryl, Jacobson, SD; Meyer, BJ; Balaough, EM et al. 2020. Vol 395 June 6, 2020

[9] WHO. COVID 19 dan Anak-anak di Indonesia Agenda Tindakan untuk Mengatasl Tantangan Sosial Ekonomi. 2020.

[10] Ferdinand K, Batieste T, Fleurestil M.2020.Contemporary and Future Concepts on Hypertension in Africans: COVID 19 and Beyond. Journal of The National Medical Association. P 1-10

[11] Li B, Yang J, Zhao F, et al. Prevalence and Impact of cardiovasculer metabolic diseases on COVID 19 in China Clin Res Cardiol.E pub ahead of Print 11 March 2020. DOI: 10.1007/s00392-020-01626-9

[12] Tignanelli CJ, Ingraham NE, Sparks $\mathrm{MA}$, et al. Antihypertensive drugs and Risk of COVID 19.Lancet Respir Med.2020; 8(5):e30-e31. Doi:10.106/S2213-2600(20)30153-3
[13] Hoffmann $M$, Kleine-Weber $H$, Schroeder S, Kruger N, Herrier T, Erichsen S, Schiergens TS; Herrier G,Wu NH, Nitsche, A Muller MA,Drosten C.Pohimann. Clinically Proven Protease Inhibitor. Cell.2020;doi:http;//dx.doi.org/10.10 16/j.cell.2020.052 pii:S0092-8674 (20)30229-4

[14] Touyz RM.Li H, Delles C.ACE2 the Janus Faced Protein-From Cardiovaskuler Protection to Severe Acute respiratory Syndrom Coronavirus and COVID 19.Clinical Science: $2020 ; 134: 747-50$

[15] Driggin E, Madhavan MV, Bikdeli B,Chuich T,Laracy J, Bondy-Zoccai $\mathrm{G}$,et al.Cardiovasculer consideration for patients, health care worker and health systems during the Coronavirus disease 2019 (COVID 19) pandemic.2020. Journal of the American College of the Cardiology.

[16] Tessaro FHG, Ayala TS,Bella LM, Martins JO.Macrofages from atype 1 diabetes mellitus mouse model present dysregulated P13K/AKT, ERK 1/2AND SAPK/JNK Levels.Immunobiology.2020;225(2):1 51879.PIMD:32283152.PMCID:PMC7 194613.https://doi.org/10/1016/j.im bio.2019.11.041 
[17] Liu Y, Yang Y,Zhang C, et al.Clinical and biochemical Indexed from 2019$n$ Cov infected patient linked to viral loads and lung injury.Sci China Life Sci 2020; 63(3):364-74 PMID: 32048163 PMCID

:PMC7088566https://doi.org/10.007/ s11427-020-1643-8

[18] Dixon AE,Peters U.The effect of obesity on lung funtion Exper Rev $\begin{array}{lll}\text { Respir Med.2018;12 (9):755-67 } & \end{array}$ PMID:30056777

PMCID:PMC6311385.https://doi.org/ 10.1080/17476348.2018.1506331
[19] Liu Wei,Tao ZW, Wang et al. 2020.Analysis of Factors associated with disease outcomes in hospitalized patient with 2019 novel coronavirus disease. Chinese Medical Journal. 2020;133(9)p 1033-1038 